\title{
The Monopoly of Capitalism in Achieving the Welfare of Indonesian Democracy
}

\author{
Hasbi $^{\text {a }}$, Rahmat Muhammad ${ }^{\mathrm{b}}$, Aryo Dwi Wibowo ${ }^{\mathrm{c}}$, Umi Faridad, Yusriadi \\ Yusriadie, ${ }^{\mathrm{a}, \mathrm{b}}$ Sociology Faculty, Universitas Hasanuddin, Makassar, \\ Indonesia, ${ }^{c} P h . D$ Candidate, Universitas Negeri Makassar, Makassar, \\ Indonesia, ${ }^{\mathrm{d}}$ Economic Faculty, STIE Amkop, Makassar, Indonesia, ${ }^{\mathrm{e}}$ Public \\ Administration Faculty, Sekolah Tinggi Ilmu Administrasi \\ Puangrimaggalatung, Makassar, Indonesia,
}

The welfare state was a great achievement of civilisation in the 20th century. In this century, the State equips civil rights and freedoms with social rights. That is why democracy and the welfare state must go hand in hand. The welfare state has freedom with millions of people from their various social origins to fight market difficulties and open opportunities in life. Among other things, economic power can identify global competition, free markets, and various kinds of public policies that are oppressive. Market liberalisation demands social and economic resilience of the people so that the tide of the free market does not displace it. The modern economy is not just a slogan, but needs to be actualised to empower the economic capabilities of the lower classes of society.

Key words: Capitalism, Democracy, Indonesia's Welfare.

\section{Introduction}

In simple terms, the welfare state theory is when a country adheres to the state administration system. The system focuses on the welfare of its people, which can be seen in the 1945 Constitution concerning objectives of the Indonesian state. It can formulate "advancing public welfare and educating the life of the nation based on the principle of social justice for all Indonesian people." The objectives contained in the opening, then listed in the body of the 1945 Constitution outlined various provisions concerning the welfare of the people. Numerous regulations regarding economic problems and people's well-being are contained in articles 27 paragraph (2), 31, 32, 33, and 34. Article 27 paragraph (2) stipulates that every 
International Journal of Innovation, Creativity and Change. www.ijicc.net

Volume 13, Issue 8, 2020

citizen has the right to work and a decent standard of living is for all of humanity. Article 31 stipulates that each citizen has the right to receive instruction.

Meanwhile, section 32 specifies the government's duty to advance national culture, and Article 34 stipulates that the state nurtures poor and abandoned children. While article 33 regulates economic problems, adheres to the family system and determines the state controls that benefit production, which are essential for the people, the earth, water, and the natural resources therein. The creation of a welfare state is initiated to reduce the level of economic inequality and eliminate poverty in the community. As a result of the gap that occurs from social welfare is the level of social strata, namely the rich get richer and poor get worse. Poverty will have an impact on the attitude of helplessness in managing life, and also harms democracy, which is the basis for issuing opinions - for example, the case of legislative elections. The poor are vulnerable to becoming victims of bribery, which has an impact and damages the system, which is counter-productive to the development of democracy in Indonesia. The welfare state was developed to reduce the level of poverty that occurred, which affected various sectors, namely economic, social, political, and cultural of a society.

Along with the development of the globalisation theory changes, which led to the gathering of the world and human civilisation in various aspects of life that resulted in the birth of the capitalist system in Indonesia. The process of globalisation strongly influences these changes and intensifies extraordinary networks of social and economic relations (Dominelli \& Hoogvelt, 1996). "Social and economic reforms are also in line with the emergence of several terms marked by the prefix "post," such as "post-industrialism," "post-Fordism," "post-structuralism" and "post-modernism" (Taylor-Gooby, 1994), (Dominelli \& Hoogvelt, 1996), (O’Brien \& Penna, 2012).

The first two terms refer to debates in the political-economic discourse, while the last two terms apply more to discussions at the cultural level. According to O'Brien \& Penna, (2012)him, the concepts above have different meanings and contextualisation. But in general, they have the same view of the old order, namely the community. The community is in a change period of global transition; and these changes are influenced primarily by the strengthening of the political-economic system of capitalism, which pivots on the ideology of neoliberalism.

Capitalism implemented in Indonesia promotes a liberal democratic system. The existence of human rights and a free-market economy has now not only permeated almost the entire development approach, but has also become a universal way of life for all civilised nations. Another method is to consider deadlock and the end of history. The famous jargon is TINA (There Is No Alternative). That is, only through the capacity of humanity can happiness and welfare be achieved. For example, when the economic crisis hit various countries, almost all 
International Journal of Innovation, Creativity and Change. www.ijicc.net

Volume 13, Issue 8, 2020

economic recovery strategies were based on the paradigm of capitalism. Many states follow the IMF and World Bank instructions; these two international institutions, are a symbol of the hegemony of global capitalism. Some things are believed to be a panacea for economic recovery. They are trade policies, the opening of foreign investors' capital markets, the recapitalisation of large industries, and the reduction of state interference in economic development. If economic growth is to advance, the role of the state must be minimised, and business power must be prioritised. Social welfare development often burdens economic growth and is a symbol of state intervention. Then a nihilistic belief develops that social welfare institutions are intrinsically uneconomic and pathological, wherever and under any conditions.

\section{Research Methods}

The method used in writing this article is a literature review. This article is a form of criticism of the implementation of a capitalist system that is said to support democracy, which will lead to a welfare state. Therefore, various questions that arise are, is it true that capitalism is the way to implement the welfare of the state? Is it right that if a country achieves a capitalist democratic system and economy, the role and commitment of the state to support justice and social welfare must wholly erode? This article provides a criticism of the application of capitalism as the panacea of economic recovery in alleviating poverty.

\section{Results and Discussion}

The welfare state was a great achievement of civilisation in the 20th century. The welfare state complements civil rights and freedom of social rights. That is why democracy and the welfare state must go hand in hand. The welfare state is the basis for a dynamic economy. It can create prosperity and renew social security and economic promises to develop the welfare state into a preventive welfare state" (Nachtwey, 2013).

Inequality of democracy leads to a liberal world that makes capitalism undermine the power of the economic sector. Meanwhile, cultural universalisation challenges us not to lose personal identity and identity as a nation. All forms of dependency and oppressive relationships must be avoided, because such things tend to undermine the dignity of society.

Capital is part of the production of other types of wealth that produces capitalism in an unlimited cycle and makes money. Capitalism is no longer directly in contact with real production and the world of work. The State has the authority to impose legal interventions to its citizens, while justice interventions are ideology. Both are living and form the core of democracy. In the past, Indonesia oscillated between three effects; wealth, capitalism, and justice. The relationship between the three must show a way out. 
International Journal of Innovation, Creativity and Change. www.ijicc.net

Volume 13, Issue 8, 2020

In a democratic system, people's sovereignty is not only upheld in the political field but also in the industrial area. If there is no economic democracy next to political democracy, the people are not yet independent. The function of political parties in Indonesia tends to change from channelling people's aspirations to being defenders of capitalism. The function of the State has also changed from advancing public welfare and educating the nation, to develop capitalism and promoting the growth of the country. At the end of World War II, only two regions of the planet were not communist, authoritarian, mercantilist, or socialist, namely North America and Switzerland. Right now, we see communist countries falling one by one, and almost all countries are not free from Coca-Cola, McDonalds, KFC, and Levi's. These are symbols of the supremacy of corporate capitalism that controls the 21 st-century economic system. However, history also shows that capitalism is not completely without problems.

In addition to the idea being misleading, many development agendas do not flow well with capitalism; problems such as environmental destruction, increasing poverty, widening social inequality, skyrocketing unemployment, human rights violations, and various other issues of moral degradation can occur. It is suspected that the problem can be the direct or indirect impact of the operation of the capitalistic economic system. According to Conway and Haque (1999) him: "compared to the socio-economic situation under the statist governments during the 1960s and 1970s, under the pro-market regimes of the 1980s and 1990s, the conditions of poverty have worsened in many African and Latin American countries in terms of an increase in the number of people in poverty, and a decline in economic growth rates, per capita income, and living standards" (Conway \& Haque, 1999).

In capitalism, the State only acts as a lookout to ensure the market mechanism runs smoothly. According to Wigley \& Lipman (1992) him, state intervention that is too large is considered disruptive to the operation of the market. Benchmarks of action are patterned utilitarianism, the principle of "as much as possible benefit from the smallest sacrifice." In practice, "benefits" often decline in meaning to merely "consumerism-materialism" and "sacrifice" which often slip into veiled oppression "the strong against the weak," "the employer against the workers," "the ruler of the ruled." Productivity, efficiency, and growth are elevated; while solidarity, effectiveness, and equality are eliminated.

That is one of the reasons why in a capitalist country, economic development and social welfare are not seen as two different and opposite "sectors." Both run harmoniously and in balance. Historical and sociological formulations frame them as the "welfare state." As the German socialist thinker Robert Heilbroner (1976) said, "the welfare state is an ideology, a system, and an effective strategy for dealing with the harmful effects of capitalism, and capitalism in the future cannot be resisted (Winter, 1976). 
International Journal of Innovation, Creativity and Change. www.ijicc.net

Volume 13, Issue 8, 2020

It is not necessary to dismantle this system completely, but rather to change the policy that is "superior", to be more humane (compassionate capitalism). The imperfection of this market mechanism, the role of government, is needed as an agent of socio-economic development. The government is not only tasked with encouraging economic growth, but also expanding commercial distribution through the allocation of public expenditure in the state budget and restrictive public policies. In addition to its national management policy, the government rewards productive economic actors. It also provides an allocation of funds and power to ensure equity and compensation for those who are excluded from the development competition. In a welfare state, solving social welfare problems, such as poverty, unemployment, inequality, and neglect, is not done through short-term partial social projects. But it is overcome in an integrated manner by social security programs, and various education, health, old age, and unemployment benefits (Wigley \& Lipman, 1992).

In a society, the role of government is a group of institutions that hold a monopoly on the use of organised power for domestic and foreign affairs. The State, as an organised political society, requires a certain level of stability in its social system to maintain its balance. To achieve this, it is not only necessary to adjust to each other's demands, and the new economic order, but also there needs to be direction towards the creation of social welfare conditions. Governments everywhere in the world have become liberal governments, both in their scope and in the number of employees needed to develop their responsibilities. Along with the increase in civil servants, it also means that an increasing number of people (these employees) can become victims of the suppression of an arbitrary regime (Bell, 1972).

In the United States, the government is the referee who applies rules to other competing communities. They have more supporters than in England and France. They also agreed to government activities such as credit supervision, or direct intervention from the government to overcome modernisation such as facilities and transportation in large urban areas and to get rid of so-called poverty (Gandy, 2008). The strength of the free market economy, which generally is included as a member of the World Trade Organisation, contributes to triggering the reform movement, including in Indonesia several years ago. Even after more than a decade of approaching two decades, the indications that won the reformation movement on domestic interests are not proven - instead of the strength of the market economy that won it. Indonesia has become a very liberal country in various sectors of life, with a crippled pace.

The International Monetary Fund (IMF) and World Bank (WB) play a role in capitalist economic power. The impact of clashes between states is entirely directed to undermine the practices of energy that are considered authoritarian and do not favour the free market. The New Order government was authoritarian in running the country, closed and implementing protection against certain economic commodities. There are four perspectives on IMF and WB policies in giving and mobilising funds to countries affected by economic crisis, 
International Journal of Innovation, Creativity and Change. www.ijicc.net

Volume 13, Issue 8, 2020

including in Indonesia. They are a) tightening monetary policy by increasing interest rates, stemming depreciation and curbing inflation; b) the formation of structuring and recapitalisation of viable institutions, while the weak are closed and merged with the stronger ones. c) Ensure fiscal policies focus on the availability of external reserves and carry out banking and system restructuring. d) Improve the public and corporate sectors of the government by designing and improving market efficiency, breaking the closeness between business and government, and increasing transparency and accountability that ensures the integration of the national economy with international financial markets (Zafra-Gómez, López-Hernández, Plata-Díaz, \& Garrido-Rodríguez, 2009).

The IMF and WB are two world financial institutions that are seen as representing the power of a capitalistic economy, which is oriented towards free-market mechanisms and politicaleconomic liberalism. According to Stiglitz (2003) the IMF and other advocates of the Washington Consensus agreement are the ones who condemn corruption the most. Still, if they are examined by those who encourage privatisation and economic liberalisation, they neglect to pay proper attention to economic growth and field creation work. The IMF and $\mathrm{WB}$ at least play a role in perpetuating the corruption with negligence.

The period of monetary crisis is a narrative of its period. Previously, the New Order era was the main story describing the knowledge of the New Order. Over 32 years in power, there are many narratives produced that can form a big story about the New Order until its collapse. Likewise, the Reformation era produced and displayed its epistemology. Each has a narrative that cannot compare, that has become dominant, and then shifted to a new narrative.

Such as; price increases for essential goods, company and banking closures, termination of employment, and flight of capital abroad. Alternatively, the story about IMF and WB is narrated as these organisation are the saviour gods of what happened. Dependence on the financial settlement of these two international banking institutions becomes another a narrative in the whole episteme, as stated by Foucault (Leventhal, 1970).

Antonio Gramsci (Montgomerie, 2008) discusses hegemony at length as a critique of capitalism as a social system, and the system based on profit motives and dominance over commodity relations, including labour commodities

With the advent of global trade, the establishment of the GATT, and turning into a WTO, free trade can be seen as exploitation on a broader scale. This scale places natural and human resources into a source of struggle. Kunio (1990) recognises that in free-market law, there are always speculators who seek profits without caring for that, which may be harmed for these actions. Not only mastering technology but also learning from the international market. From there, thinking about capitalism with the principles of a free market economy continues to develop. Critical assumptions about the relations of the market economy, state intervention, 
International Journal of Innovation, Creativity and Change. www.ijicc.net Volume 13, Issue 8, 2020

and democratisation seem to be central themes. An authoritarian state is associated with a closed system of economic practice, whereas countries that use free-market mechanisms are related to freedom.

At the same time, issues concerning clean governance, empowerment of civil society, and law enforcement are inherently characteristic. If we look carefully, what happened in Indonesia at the time of the 1998 economic crisis, can be dissected with these analyses and assumptions. Rent-seeking practices characterise businesses in Indonesia. The distribution of business opportunities occurs with limitations and restrictions. The relationship between economics and justice is directly proportional. Freedom and a free market economy embraced in capitalism is seen as a beneficial recipe applied everywhere and in any country. But in some facts, it shows that the market mechanism never runs perfectly. There is a gap in the free-market arrangement of the economy so that positive control occurs over the others.

The free market has been scientifically proven not to work correctly (Stiglitz, 2003). Ideally, an entirely free market can only work if there is perfect information. Whereas the perfection of data from the amount of information received, how to obtain information, how it flows, is almost certainly unable to be controlled as desired. Each party seeks to monitor and control specific sources of information so that perfect information conditions will never occur. Stiglitz said that market conditions are always in a situation of information asymmetry that is still an imbalance of information. In such a case, an ideal and perfect free-market economy will never occur. The market is always in a state of imperfection. Therefore, the market requires regulation, and hegemonic power must not lead it. In this context, the regulator that controls and regulates market mechanisms is the government. Speculative capitalist hegemonic forces will fill the void of the State or government in a free market economic mechanism. The orientation is just for profit-seeking regardless of the loss of other parties. Indonesia, as a country, has taken a firm position that sees in the fundamental laws of the country. The State controls the earth, water, wealth for people in perpetuity. This means, in such a position, the Indonesian government must be involved in the regulation and control of economic resources so that the power of capitalism does not control them.

A currency crisis can occur at any time and remains a threat that continues to haunt developing countries. The crisis did not happen in 1998 alone and if it did not happen again, the market economy mechanism can still work wildly. By operating in the power of capitalism does not rule out the economic system of a nation collapsing. The hard work of advancing democracy becomes meaningless when the currency used in a capitalist state experiences a drastic decline in value.

In 1998, until the 1999 fiscal year the government assumed the IDR exchange rate at the level of 5,000, where the parameters set, used a reference to the world crude oil price of US $\$$ 
International Journal of Innovation, Creativity and Change. www.ijicc.net

Volume 13, Issue 8, 2020

17/barrel. But in real terms, on the market, in May 1998, the exchange rate of the rupiah against the US dollar reached 8,000 - more (YKPI, 2000: 11). The government tried hard to control the volatile movements of the rupiah exchange rate, economic and political stability, which was the basis of the legitimacy of the New Order regime at that time, which caused widespread distrust among the Indonesian people. The government was described as a failure in resolving the crisis - the move to raise bank interest rates to 45 percent was considered to have worsened the situation. Market interventions carried out by Bank Indonesia of up to 10 billion US dollars, remained unable to control the anomaly of the rupiah on the money market. Even at a certain level, the government no longer has room to carry out policies. Because at the same time, whatever the government does, it must be approved by the IMF and WB as compensation for the disbursement of loan funds to the Indonesian government. For example, the government plans to implement a Currency Board System, but the plan was not applied immediately.

Denis de Tray (Head of WB Jakarta representative) ensured that Indonesia experienced a dead-end in resolving the economic crisis. According to him, the Indonesian government must realise there is no magic drug that can cure this financial crisis immediately. The steps required by the IMF must first be taken to regain trust. According to Alan Wood and Ted Grant the international financial police named the IMF and WB to oversee the implementation of economic reforms that are required. Like an eagle, they perched to ensure that every penny of debt was paid for the suffering caused by painful sanctions. The impacts of the financial crisis that occurred in 1998, can still be felt now, and the process of change, the handling of the situation, and control is carried out by forces that come from outside. Large financial institutions took a role in dictating their interests during the crisis regardless of the extent of risks to the population. Capitalism's economic power will slowly bring all the benefits and place Indonesia in charge in its own interests and control of liberalisation and a free market economy.

\section{Conclusion}

The policy did not show good results. Even the IMF and WB themselves play a role in perpetuating corruption with negligence. The presence of capitalism monopolises the entire economic system. Now more and more observers are suing, whether the system that underlies free-market competition can answer a variety of national and global problems or not. History also shows that capitalism is not without issues or a perfect tool. In addition to the notion that it is often misleading, many development agendas do not flow clearly with capitalism. Problems such as environmental destruction, increasing poverty, widening social inequality, skyrocketing unemployment, and the spread of human rights violations and various other issues of moral degradation, are suspected to be the direct or indirect impact of the operation of a capitalist economic system. Capitalism has not only failed to overcome the development 
International Journal of Innovation, Creativity and Change. www.ijicc.net

Volume 13, Issue 8, 2020

crisis, but has worsened the socio-economic conditions in the There is a need to improve the concept and policy system that starts from a strong generation and is not easily swayed by the influence and the lure of misleading the State. 
International Journal of Innovation, Creativity and Change. www.ijicc.net

Volume 13, Issue 8, 2020

\section{REFERENCES}

Bell, D. (1972). The Cultural Contradictions of Capitalism. The Journal of Aesthetic Education, 6(12), 11-38. https://doi.org/10.2307/3331409

Conway, M. A., \& Haque, S. (1999). Overshadowing the Reminiscence Bump: Memories of a Struggle for Independence. Journal of Adult Development, 6, 35-44. https://doi.org/https://doi.org/10.1023/A:1021672208155

Dominelli, L., \& Hoogvelt, A. (1996). Globalization and the technocratization of social work. $\begin{array}{lll}\text { Critical Social Policy, } & \text { 16(47). }\end{array}$ https://doi.org/https://doi.org/10.1177\%2F026101839601604703

Gandy, M. (2008). Landscapes of Disaster: Water, Modernity, and Urban Fragmentation in Mumbai. Environment and Planning A: Economy and Space, 40(1), 108-130. https://doi.org/https://doi.org/10.1068\%2Fa3994

Leventhal, H. (1970). Findings and Theory in the Study of Fear Communications. Advances in Experimental Social Psychology, 5, 119-186. https://doi.org/https://doi.org/10.1016/S0065-2601(08)60091-X

Montgomerie, J. (2008). Bridging the critical divide: global finance, financialisation and contemporary capitalism. Journal Contemporary Politics, 14(3), 233-252. https://doi.org/https://doi.org/10.1080/13569770802396303

Nachtwey, O. (2013). Market Social Democracy: The Transformation of the SPD up to 2007. Journal German Politics, 22(3), 235-252. https://doi.org/Market Social Democracy: The Transformation of the SPD up to 2007

O’Brien, M., \& Penna, S. (2012). Postmodern theory and politics: Perspectives on citizenship and social justice. Journal Innovation: The European Journal of Social Science Research, 9(2), 185-203. https://doi.org/https://doi.org/10.1080/13511610.1996.9968483

Olssen, M. (2006). Understanding the mechanisms of neoliberal control: lifelong learning, flexibility and knowledge capitalism. Journal International Journal of Lifelong Education, 25(3), 213-230. https://doi.org/https://doi.org/10.1080/02601370600697045

Stiglitz, J. E. (2003). Democratizing the International Monetary Fund and the World Bank: Governance and Accountability. Governance A International Journal of Policy, Administration and Institution, 16(1), 111-139. https://doi.org/https://doi.org/10.1111/1468-0491.00207 
International Journal of Innovation, Creativity and Change. www.ijicc.net Volume 13, Issue 8, 2020

Taylor-Gooby, P. (1994). Postmodernism and Social Policy: A Great Leap Backwards? $\begin{array}{lllll}\text { Journal of } & \text { Social } & \text { Policy, } & 23(3), & \end{array}$ https://doi.org/https://doi.org/10.1017/S0047279400021917

Wigley, J., \& Lipman, C. (1992). Does Capitalism Compete with Morality? The Enterprise Economy, 3(1), 29-43. https://doi.org/https://doi.org/10.1007/978-1-349-22037-3_3

Winter, G. (1976). Reviewed Works: Business Civilization in Decline by Robert L. Heilbroner; Zygon, Journal of Religion \& Science. Journal for the Scientific Study of Religion, 15(4), 369-372. https://doi.org/10.2307/1385640

Zafra-Gómez, J. L., López-Hernández, A. M., Plata-Díaz, A. M., \& Garrido-Rodríguez, J. C. (2009). Developing an alert system for local governments in financial crisis. Journal $\begin{array}{llll}\text { Public Money \& } \quad \text { Management, } & \text { 29(3), }\end{array}$ https://doi.org/https://doi.org/10.1080/09540960902891731 